\title{
PENGARUH LINGKUNGAN KERJA DAN REWARD TERHADAP KINERJA KARYAWAN
}

\author{
Ferry Kartawijaya, Sabil,Amin Setio Lestiningsih, Dwiyatmoko Puji Widodo \\ Universitas Bina Sarana Informatika, Indonesia \\ E-mail: ferry.frk@bsi.ac.id
}

\begin{abstract}
ABSTRAK
Tujuan dari penelitian ini adalah untuk menguji pengaruh lingkungan kerja dan penghargaan terhadap kinerja karyawan. Penelitian ini dilakukan di berbagai tempat untuk mengumpulkan responden. Ini dilakukan untuk mendapatkan responden dengan mudah. Populasi dan sampel yang terlibat dalam penelitian ini adalah karyawan PT Daya Cipta Dianrancana yang terdiri dari 150 responden. Teknik dalam menganalisis pengaruh lingkungan kerja dan penghargaan terhadap kinerja, peneliti menggunakan SPSS. Hasil analisis menunjukkan bahwa ada pengaruh yang signifikan antara lingkungan kerja dan penghargaan terhadap kinerja. Ini berarti bahwa lingkungan kerja yang lebih baik dan lebih banyak penghargaan akan meningkatkan motivasi untuk bekerja lebih keras dan akhirnya akan meningkatkan efisiensi dan efektifitas bagi perusahaan.
\end{abstract}

Primary key : Pengaruh, Lingkungan Kerja, Reward, Kinerja Karjawan

\section{Pendahuluan}

Kerjasama dalam organisasi sangat berperan penting dalam mewujudkan tujuan organisasi. Kerjasama merupakan jiwa interaksi sosial dalam kehidupan bermasyarakat. Begitu pula di dalam organisasi diperlukan kerjasama untuk menjalin hubungan yang harmonis dan tukar menukar informasi antara pimpinan organisasi dengan anggota organisasi atau sebaliknya dari anggota organisasi dengan pimpinan organisasi dan antar sesama anggota organisasi.

Hubungan yang dilakukan oleh unsur pimpinan antara lain untuk kelangsungan hidup berorganisasi untuk mencapai perkembangan ke arah yang lebih baik dengan menciptakan hubungan kerja sama dengan bawahannya. Relasi yang dilakukan oleh bawahan sudah tentu mengandung maksud untuk mendapatkan simpati dari pimpinan yang merupakan motivasi untuk meningkatkan prestasi kerja ke arah yang lebih baik. Hal ini tergantung dari kebutuhan dan cara masing-masing individu, karena satu sama lain erat hubungannya dengan keahlian dan tugas-tugas yang harus dilaksanakan, dan menghasilkan kepuasan kerja.

Pada dasarnya, prinsip-prinsip kepuasan kerja diarahkan kepada pemenuhan kebutuhankebutuhan karyawan. Bahwa kepuasan kerja merupakan kondisi emosional positif atau menyenangkan yang dihasilkan dari penilaian karyawan berdasarkan pengalamannya. Lebih jauh lagi, kepuasan kerja merupakan reaksi efektif karyawan terhadap pekerjaannya, tergantung kepada taraf pemenuhan kebutuhan-kebutuhan fisik dan psikologis karyawan tersebut oleh pekerjaannya. Kesenjangan antara yang diterima karyawan dari pekerjaannya dengan yang diharapkannya menjadi dasar bagi munculnya kepuasan atau ketidakpuasan.

Perusahaan dalam kegiatannya pun selalu memenuhi beragam kebutuhan dari karyawannya, perusahaan selalu berusaha untuk memenuhi semua kebutuhan karyawan baik dari segi moril maupun materil, seperti pemberian gaji, bonus, rekreasi dan lainnya. Namun dari apa yang dilakukan perusahaan tersebut ada saja karyawan yang merasa kurang dan akhirnya berdampak pada kinerja yang buruk pada perusahaan. Banyak keluhan yang dilontarkan karyawan, mulai dari anggapan karyawan tentang pimpinan yang pilih kasih dalam penugasan, sarana prasarana yang tidak memadai, bonus yang tidak merata, gaji yang kurang (kecil) hingga penghargaan lain yang tidak didapat. Apabila hal ini dibiarkan dan terus berlanjut maka tentu akan menjadi berakibat buruk bagi perusahaan ke depan. 
Hasil penelitian yang dilakukan di PT. Perusahaan Gas Negara (Persero) Tbk SBU Distribusi Wilayah I Jakarta dapat memberikan masukan atau informasi kepada pimpinan perusahaan bahwa dengan memperhatikan lingkungan kerja yang terdapat pada instansi itu akan berpengaruh terhadap kinerja pegawai (Budianto dan Amelia Kartini, 2015). Penelitian yang dilakukan oleh Wasiati (2018) reward berpengaruh positif dan non signifikan terhadap kepuasan kerja pegawai, artinya pemberian reward akan meningkatkan kepuasan kerja pegawai.

\section{Tinjauan Literatur}

\subsection{Kinerja Karyawan}

Setiap individu yang diberi tugas atau kepercayaan untuk bekerja pada suatu organisasi tertentu diharapkan mampu menunjukkan kinerja yang memuaskan dan memberikan konstribusi yang maksimal terhadap pencapaian tujuan organisasi tersebut.

Kinerja pada hakikatnya merupakan hasil kerja seseorang dalam melaksanakan pekerjaannya. Menurut (Ivancevich , 2011) Kinerja merupakan hasil yang diharapkan dari perilaku seseorang dalam melaksanakan suatu pekerjaan. Pendapat sederhana ini menunjukkan bahwa kinerja pada hakikatnya merupakan hasil unjuk kerja seseorang dalam melaksanakan pekerjaan.

Menurut (Colquitt, 2009) Kinerja adalah perilaku karyawan yang berkontribusi positif atau negatif terhadap pencapaian tujuan organisasi. Definisi tersebut mengandung pengertian bahwa melalui kinerja, tingkat pencapaian organisasi dapat diketahui. Pencapaian atas tujuan organisasi tersebut kemudian dijadikan sebagai tolak ukur untuk menilai baik atau buruknya kinerja organisasi.

\subsection{Lingkungan Kerja}

Persepsi tentang lingkungan kerja memang bermacam-macam, (Schermerhorn, 2010) mengemukakan bahwa ada dua macam lingkungan kerja, yaitu: lingkungan umum dan lingkungan khusus. Lingkungan umum mencakup nilai-nilai kultural, kondisi ekonomi, pendidikan, politik dan hukum. Sedangkan lingkungan khusus berkaitan dengan posisi organisasi itu sendiri dalam upaya mengembangkan jaringan organisasinya. Batasan ini menunjukkan bahwa lingkungan yang berkaitan dengan upaya organisasi dalam mengembangkan diri.

Menurut Mardiana (2005), lingkungan kerja adalah lingkungan di mana pegawai melakukan pekerjaannya sehari-hari. Sedarmayanti (2001) menyatakan bahwa secara garis besar, jenis lingkungan kerja terbagi menjadi 2 yakni lingkungan kerja fisik dan lingkungan kerja nonfisik. Lingkungan kerja fisik adalah semua keadaan berbentuk fisik yang terdapat di sekitar tempat kerja yang dapat memengaruhi karyawan baik secara langsung maupun scara tidak langsung. Lingkungan kerja fisik dapat dibagi dalam dua kategori, yakni: (1) lingkungan yang langsung berhubungan dengan karyawan, seperti: pusat kerja, kursi, meja dan sebagainya; (2) lingkungan perantara atau lingkungan umum dapat juga disebut lingkungan kerja yang memengaruhi kondisi manusia, misalnya: temperatur, kelembaban, sirkulasi udara, pencahayaan, kebisingan, getaran mekanis, bau tidak sedap, warna, dan lain-lain. Untuk dapat memperkecil pengaruh lingkungan fisik terhadap karyawan, maka langkah pertama adalah harus mempelajari manusia, baik mengenai fisik maupun tingkah lakunya, yang kemudian digunakan sebagai dasar memikirkan lingkungan fisik yang sesuai. 


\subsection{Reward}

Pemberian reward berdasarkan kinerja didasarkan atas teori kesetaraan (Equity Theory) dan teori harapan (Expectancy Theory). Teori Kesetaraan menyatakan bahwa setiap karyawan harus diperlakukan secara adil dan setara. Teori harapan menyatakan bahwa seseorang percaya bahwa apabila karyawan mampu mencapai tingkat kinerja tertentu maka karyawan tersebut akan memperoleh imbalan. Secara historis, teori kesetaraan berfokus pada keadilan distributif atau keadilan yang dipahami berdasarkan banyaknya dan alokasi imbalan ke sejumlah individu. Tetapi kesetaraan juga harus mempertimbangkan kesataraan prosedural, kesetaraan yang dipersepsikan dari proses yang digunakan untuk menentukan distribusi imbalan. Teori harapan berfokus pada tiga hubungan :

1) hubungan upaya-kinerja,

2) hubungan kinerja-imbalan,

3) hubungan imbalan-tujuan.

Sutrisno (2009) berpendapat bahwa reward atau penghargaan adalah balas jasa yang diberikan perusahaan kepada karyawan atas dasar pengorbanan waktu, tenaga, dan pikiran. Reward diklasifikasikan ke dalam dua kategori, yaitu penghargaan ekstrinsik dan penghargaan intrinsik (Ivancevich, 2006)

\section{Metodologi Penelitian}

Penelitian ini menggunakan pendekatan kuantitatif, yaitu penelitian yang memfokuskan pada pengujian hipotesis, dengan menggunakan data yang dapat diukur untuk mengambil kesimpulan, yaitu semua jawaban responden akan dilakukan Scoring (skala likert dengan gradasi 1 sampai 5). Penelitian dilaksanakan pada PT. Daya Cipta Dianrancana yang berkantor pusat di Bandung. PT. Daya Cipta Dianrancana adalah perusahaan yang bergerak di bidang jasa Konsultan Perencanaan teknik, yang didirikan di Bandung pada tahun 1997, dan dikelola oleh managemen yang profesional dan berpengalaman. Sebagai perusahaan jasa konsultansi perencanaan teknik, PT. Daya Cipta Dianrancana didukung oleh tenaga-tenaga profesional dengan latar pendidikan dibidang engineering dan lainnya serta mempunyai pengalaman kerja dengan standarisasi IAI, CSI dan ASHARE yang cukup menjamin kemampuan dan keahlian perusahaan dalam menangani proyek-proyeknya. Sejak berdirinya hingga sekarang, perusahaan ini telah cukup mempunyai pengalaman kerja dalam menangani proyek-proyek skala nasional di Indonesia.

\section{Hasil dan Pembahasan 4.1.Demografi Responden}

Tabel 1.Demografi responden berdasarkan jenis kelamin.

\begin{tabular}{|c|c|c|c|c|c|c|}
\hline & & Frequency & $\begin{array}{l}\text { Percen } \\
\mathrm{t}\end{array}$ & $\begin{array}{l}\text { Valid } \\
\text { Percent }\end{array}$ & $\begin{array}{c}\text { Cumulative } \\
\text { Percent }\end{array}$ & \\
\hline & Pria & 94 & 62,7 & 62,7 & 62,7 & \\
\hline & wanita & 56 & 37,3 & 37,3 & 100,0 & \\
\hline $\begin{array}{l}\text { Dari tabel } 1 \\
\text { bahwa dari }\end{array}$ & Total & 150 & 100,0 & 100,0 & & $\begin{array}{l}\text { diatas terlihat } \\
\text { jumlah } \quad 150\end{array}$ \\
\hline
\end{tabular}


Tabel 2. Demografi responden berdasarkan Usia.

\begin{tabular}{llrrrr}
\hline & & Frequency & Percent & Valid Percent & \multicolumn{2}{c}{$\begin{array}{c}\text { Cumulative } \\
\text { Percent }\end{array}$} \\
\hline \multirow{2}{*}{ Valid } & 20s/d25 & 91 & 60,7 & 60,7 & 60,7 \\
\cline { 2 - 6 } & $26 \mathrm{~s} / \mathrm{d} 35$ & 59 & 39,3 & 39,3 & 100,0 \\
\cline { 2 - 6 } & Total & 150 & 100,0 & 100,0 & \\
\hline
\end{tabular}

Pada tabel 2 diatas bahwa dari jumlah 150 respoden yang berusia $20 \mathrm{~s} / \mathrm{d} 25$ sebanyak 91 responden atau sebesar $60,7 \%$ dan $26 \mathrm{~s} / \mathrm{d} 35$ sebanyak 59 responden atau sebesar 39,3\%

Tabel 3. Demografi responden berdasarkan pendidikan terakhir.

\begin{tabular}{|c|c|c|c|c|c|}
\hline & & Frequency & Percent & $\begin{array}{l}\text { Valid } \\
\text { Percent }\end{array}$ & $\begin{array}{l}\text { Cumulative } \\
\text { Percent }\end{array}$ \\
\hline \multirow[t]{5}{*}{ Valid } & SMA/sederajad & 7 & 4.7 & 4.7 & 4.7 \\
\hline & Diploma/Strata 1 & 39 & 26.0 & 26.0 & 30.7 \\
\hline & Strata 2 & 87 & 58.0 & 58.0 & 88.7 \\
\hline & Strata 3 & 17 & 11.3 & 11.3 & 100.0 \\
\hline & Total & 150 & 100.0 & 100.0 & \\
\hline
\end{tabular}

Pada tabel 3 diatas bahwa dari jumlah 150 respoden yang tamat SMA/Sederajat sebanyak 7 responden atau sebesar 4,7 \%, Diploma/Strata 1 sebanyak 39 responden atau sebesar $26 \%$, Strata 2 sebanyak 87 responden atau sebesar $58 \%$ dan Strata 3 sebanyak 17 responden setara dengan $11,3 \%$.

Tabel 4. Demografi responden berdasarkan pendapatan perbulan

\begin{tabular}{|c|c|c|c|c|c|}
\hline & & Frequency & Percent & $\begin{array}{c}\text { Valid } \\
\text { Percent }\end{array}$ & $\begin{array}{l}\text { Cumulativ } \\
\text { e Percent }\end{array}$ \\
\hline \multirow[t]{5}{*}{ Valid } & $\leq \mathrm{Rp} .2 .500 .000$ & 7 & 4.7 & 4.7 & 4.7 \\
\hline & $\begin{array}{l}\text { Rp. } 2.500 .000 \mathrm{~s} / \mathrm{d} \mathrm{Rp} \\
4.000 .000\end{array}$ & 30 & 20.0 & 20.0 & 24.7 \\
\hline & $\begin{array}{l}\text { Rp. } 4.000 .000 \mathrm{~s} / \mathrm{d} \\
\text { Rp.6.000.000 }\end{array}$ & 93 & 62.0 & 62.0 & 86.7 \\
\hline & $\geq$ Rp. 6.000 .000 & 20 & 13.3 & 13.3 & 100.0 \\
\hline & Total & 150 & 100.0 & 100.0 & \\
\hline
\end{tabular}

Pada tabel 4 diatas bahwa dari jumlah 150 respoden yang pendapatan < Rp2.500.000 sebanyak 7 responden atau 4,7 \%, pendapatan Rp 2.500.000 s/d Rp 4.000.000 sebanyak 30 responden atau $20 \%$, pendapatan $\mathrm{Rp} 4.000 .000 \mathrm{~s} / \mathrm{d} \mathrm{Rp} 6.000 .000$ sebanyak 93 responden atau $62 \%$ dan yang berpenghasilan diatas Rp 6.000 .000 sebanyak 20 responden atau $13,3 \%$

Tabel 5.Demografi responden berdasarkan bidang keahlian

\begin{tabular}{|c|c|c|c|c|c|}
\hline & & Frequency & Percent & $\begin{array}{c}\text { Valid } \\
\text { Percent }\end{array}$ & $\begin{array}{c}\text { Cumulative } \\
\text { Percent }\end{array}$ \\
\hline \multirow[t]{5}{*}{ Valid } & sipil & 55 & 36,7 & 36,7 & 36,7 \\
\hline & arsitektural & 59 & 39,3 & 39,3 & 76,0 \\
\hline & keuangan & 29 & 19,3 & 19,3 & 95,3 \\
\hline & transportasi & 7 & 4,7 & 4,7 & 100,0 \\
\hline & Total & 150 & 100,0 & 100,0 & \\
\hline
\end{tabular}


Dari tabel 5 diatas bahwa dari jumlah 150 respoden yang bidang keahliannya sipil sebanyak 55 responden atau 36,7 \%, arsitektural sebanyak 59 responden atau 39,3\%, keuangan sebanyak 29 responden atau $19,3 \%$, transportasi sebanyak 7 responden atau $4,7 \%$.

\subsection{Deskripsi Data}

Deskriptif data merupakan ringkasan jawaban yang diberikan responden terhadap pernyataanpernyataan dalam kuesioner. Statistik deskriptif bertujuan untuk memberikan gambaran atau deskripsi suatu data yang ditinjau dari nilai minimum, nilai maksimum, nilai rata-rata (mean), dan standar deviasi. Dalam penelitian ini digunakan SPSS 17. untuk menganalisa. Dimana mean adalah nilai rata-rata dari keseluruhan responden, sedangkan standar deviasi menunjukan variasi dari jawaban respoden. Nilai minimum adalah jawaban (skala1) terendah yang dipilih responden. Demikian pula nilai maksimum adalah jawaban (skala 5) tertinggi yang dipilih responden.

\subsection{Uji Validitas dan Realibilitas Data}

Uji validitas digunakan untuk menguji sejauh mana suatu alat ukur ( kuesioner ) mengukur apa yang ingin diukur. Syarat yang harus dipenuhi adalah korelasinya ( nilai $r$ ) harus positif ( bisa dilihat pada corrected item -total correlation Pada SPSS Versi 17), nilai $\mathrm{r}$ ( koofisien korelasi ) hitung harus $>r$ tabel. Dengan 30 responden maka dicari $r$ tabel pada signifikansi 0,05 dengan uji 2 sisi dan jumlah data $\mathrm{n}=30, \mathrm{df}=\mathrm{n}-2, \mathrm{df}=30-2=28$, maka didapat $\mathrm{r}$ tabel $=0,360$, korelasi yang digunakan dalam pengujian validitas instrumen adalah metode corrected item-total correlation menggunakan program SPSS release 17 for windows.

\subsection{Uji Realibilitas Data}

Tabel 6. Data Realibilitas

\begin{tabular}{cccc}
\hline Variabel & $\begin{array}{c}\text { Koefisien } \\
\text { (Nilai } \\
\text { Alpha } \\
\text { Cronbach) }\end{array}$ & $\begin{array}{c}\text { Nilai } \\
\text { Kritis }\end{array}$ & Ket. \\
\hline $\begin{array}{c}\text { Lingkungan } \\
\text { kerja (X1) }\end{array}$ &, 898 & 0,60 & Reliabel \\
\hline Reward(X2) &, 889 & 0,60 & Reliabel \\
\hline $\begin{array}{c}\text { Kinerja } \\
\text { kary (Y) }\end{array}$ &, 896 & 0,60 & Reliabel \\
\hline
\end{tabular}

Dilihat pada tabel diatas semua variabel menghasilkan koefisien Alpha Cronbach lebih besar dari 0.60. dengan demikian, seluruh butir instrumen dinyatakan reliabel.

\subsection{Pengujian Hipotesis}

\subsubsection{Pengaruh Lingkungan KerjaTerhadap Reward}

Berdasarkan pengolahan data dengan bantuan komputer melalui program SPSS diperoleh sebagai berikut: 
Tabel 7.Model Summary

\begin{tabular}{lccrrr}
\hline Model & R & R Square & $\begin{array}{c}\text { Adjusted R } \\
\text { Square }\end{array}$ & $\begin{array}{c}\text { Std. Error of the } \\
\text { Estimate }\end{array}$ & Durbin-Watson \\
\hline 1 & $.034^{\mathrm{a}}$ & .001 & -.006 & 5.462219 & 1.649 \\
\hline a. Predictors: (Constant), ling_kerja & & & & \\
b.Dependent Variable: reward & & & & &
\end{tabular}

Tabel 8. Coefficients

\begin{tabular}{|c|c|c|c|c|c|c|c|}
\hline \multirow[b]{2}{*}{ Model } & \multicolumn{2}{|c|}{ Unstandardized Coefficients } & \multirow{2}{*}{$\begin{array}{c}\begin{array}{c}\text { Standardized } \\
\text { Coefficients }\end{array} \\
\text { Beta }\end{array}$} & \multirow[b]{2}{*}{$\mathrm{t}$} & \multirow[b]{2}{*}{ Sig. } & \multicolumn{2}{|c|}{ Collinearity Statistics } \\
\hline & $\mathrm{B}$ & Std. Error & & & & Tolerance & VIF \\
\hline 1 (Constant) & 29.523 & 3.561 & & 8.290 & .000 & & \\
\hline ling_kerja & .025 & .060 & .034 & .414 & .679 & 1.000 & 1.000 \\
\hline
\end{tabular}

Berdasarkan perhitungan diperoleh angka korelasi antara lingkungan kerja terhadap peningkatan reward sebesar 0,034. Korelasi sebesar 0,034 artinya hubungan antara lingkungan kerja terhadap peningkatan reward bersifat sangat rendah tetapi searah (karena hasilnya positif), searah artinya jika lingkungan kerja tinggi maka peningkatan reward juga tinggi. Besarnya angka R Square $\left(r^{2}\right)$ sebesar 0,001, Angka tersebut mempunyai maksud bahwa tidak ada pengaruh antara lingkungan kerja terhadap peningkatan reward.

Dari tabel koefisien dapat dikatakan:

\section{Persamaan Regresi}

$\mathrm{Y}=29,523+0,025 \mathrm{X} 1$

a. 29,523 artinya jika tidak ada pengaruh lingkungan kerjaterhadap peningkatan reward pada dasarnya reward memiliki nilai 29,523.

b. $X_{1}$ 0,025 artinya jika nilai lingkungan kerja bertambah sebesar satu satuan, maka peningkatan reward bertambah 0,025

\section{Hasil Uji Hipotesis}

$\mathrm{T}$ hitung $=0,414$, dibandingkan dengan $\mathrm{t}$ tabel dan untuk menentukan $\mathrm{t}$ tabel $=$ tabel distribusi t dicari pada $\alpha=5 \%$ dengan derajat kebebasan $\mathrm{df}=\mathrm{n}-\mathrm{k}-1=150-1-1=148(\mathrm{n}$ : jumlah sampel dan $\mathrm{k}$ : jumlah variabel bebas dalam hal ini ( hanya reward). hasil yang diperoleh untuk $\mathrm{t}$ tabel sebesar 1,655 yang menggunakan taraf kesalahan 5\% diperoleh nilai t tabel $=1,655$, jadi $\mathrm{t}$ hitung $\leq \mathrm{t}$ tabel $(0,414<1,655)$, maka Ho diterima dan Ha ditolak, artinya tidak ada pengaruh antara lingkungan kerja terhadap peningkatan reward. 


\subsubsection{Pengaruh Lingkungan kerja (X1), dan Reward (X2) Terhadap PeningkatanKinerjaKaryawan (Y)}

Berdasarkan pengolahan data dengan bantuan komputer melalui program SPSS versi 17.0 diperoleh sebagai berikut :

Tabel 9. Model Summary ${ }^{\mathrm{b}}$

\begin{tabular}{lrrrrr}
\hline $\begin{array}{l}\text { Mode } \\
1\end{array}$ & R & R Square & $\begin{array}{c}\text { Adjusted R } \\
\text { Square }\end{array}$ & $\begin{array}{l}\text { Std. Error of } \\
\text { the Estimate }\end{array}$ & $\begin{array}{l}\text { Durbin- } \\
\text { Watson }\end{array}$ \\
\hline 1 &, $382^{\mathrm{a}}$ &, 146 &, 135 & 6,756123 & 1,702 \\
\hline
\end{tabular}

a. Predictors: (Constant), X2_REWAD, X1_LNGK_KERJA

b.Dependent Variable: Y_KINERJA_KRY

Tabel 10. ANOVAa

\begin{tabular}{ccccccc}
\hline & Model & Sum of Squares & df & Mean Square & F & Sig. \\
\hline \multirow{3}{*}{1} & Regression & 1149,625 & 2 & 574,812 & 12,593 &, $000^{b}$ \\
\cline { 2 - 7 } & Residual & 6709,844 & 147 & 45,645 & & \\
\cline { 2 - 7 } & Total & 7859,468 & 149 & & & \\
\hline
\end{tabular}

a. Dependent Variable: Y_KINERJA_KRY

b. Predictors: (Constant), X2_REWAD, X1_LNGK_KERJA

\begin{tabular}{|c|c|c|c|c|c|c|}
\hline & \multirow[t]{2}{*}{ Model } & \multicolumn{2}{|c|}{ Unstandardized Coefficients } & \multirow{2}{*}{$\begin{array}{l}\text { Standardized } \\
\text { Coefficients }\end{array}$} & \multirow[t]{2}{*}{$\mathrm{t}$} & \multirow[t]{2}{*}{ Sig. } \\
\hline & & $\mathrm{B}$ & Std. Error & & & \\
\hline \multirow{3}{*}{1} & (Constant) & 25,516 & 5,330 & & 4,787 & 000 \\
\hline & X1_LNGK_KERJA & ,197 &, 074 & ,202 & 2,651 & ,009 \\
\hline & X2_REWARD & ,424 &, 102 & ,318 & 4,168 & 000 \\
\hline
\end{tabular}

Berdasarkan perhitungan diperoleh angka korelasi lingkungan kerja (X1), dan reward (X2) terhadap peningkatan kinerja karyawan (Y) sebesar 0,202 (X1), 0,318 (X2) artinya hubungan antara lingkungan kerja (X1), dan reward (X2) terhadap peningkatan kinerja karyawan (Y) bersifat sedang dan searah (karena hasilnya positif), searah artinya jika lingkungan kerja (XI) dan reward (X2) tinggi maka peningkatan kinerja karyawan ( Y ) juga tinggi.

Besarnya angka Adjusted $\mathrm{R}$ Square $\left(\mathrm{r}^{2}\right)$ sebesar 0,135 angka tersebut dapat digunakan untuk melihat pengaruh lingkungan kerja (X1), dan reward(X2) terhadap peningkatan kinerja karyawan (Y) (koefisien determinan). Angka tersebut mempunyai maksud bahwa pengaruh mutu produk terhadap peningkatan penjualan adalah $13,5 \%$ dan sisanya dipengaruhi variabel lain sebesar $77,5 \%$.

Dari tabel koefisien dapat dikatakan

\section{Persamaan Regresi}

$\mathrm{Y}=25,516+0,197 \mathrm{X} 1+0,424 \mathrm{X} 2$

a. 25,516 artinya jika tidak ada pengaruh lingkungan kerja (X1), dan reward (X2) terhadap peningkatan kinerja karyawan (Y)pada dasarnya memiliki nilai 25,516

$\mathrm{x}_{1}=$ 0,197 artinya jika nilai lingkungan kerja (X1) ditingkatkan sebesar satu kesatuan , dengan asumsi kinerja karyawan (Y) konstan, maka akan meningkatkan kinerja karyawan (Y) bertambah 0,479 . 
$\mathrm{x}_{2}=0,424$ jika Reward (X2) ditingkatkan sebesar satu kesatuan, dengan asumsi kinerja karyawan (Y) konstan maka peningkatan kinerja karyawan (Y) bertambah 0,424

\section{Hasil Uji Hipotesis}

$\mathrm{F}$ hitung $=12,593$, dibandingkan dengan $\mathrm{F}$ tabel dengan menggunakan tingkat keyakinan $95 \%, \alpha=5 \%$, df1 ( Jumlah Variabel -1 ) maka df1 = 3-1 = 2 dan df2 = n-k-1 atau 150-2-1 = 147 ( $\mathrm{n}$ adalah jumlah sampel populasi dan $\mathrm{k}$ adalah jumlah variabel independen) hasil yang diperoleh untuk F tabel sebesar 3,0563., jadi $\mathrm{F}$ hitung > F tabel $(12,593>3,0563)$, maka Ho ditolak dan Ha diterima, artinya ada pengaruh antara Lingkungan kerja (X1), dan Reward (X2) terhadap peningkatan kinerja karyawan (Y) pada PT.Daya Cipta Dianrancana Bandung.

\section{Kesimpulan}

Dari penjelasan pada bagian sebelumnya dapat disimpulkan bahwa :

a. Lingkungan Kerja yang ada pada PT Daya Cipta Dianrancanasudah cukup kondusif, dan akan mempengaruhi kinerja para karyawannya, yang akan berpengaruh positif bila diperoleh kondisi yang nyaman, tenang, dan harmonis.

b. Reward yang berlaku di lingkungan PT DayaCiptaDianrancana, ternyata juga dapat mempengaruhi Kinerja Karyawan, dimana karyawan akan semakin meningkat Kinerjanya apabila karyawan mendapatkan reward yang sesuai dengan apa yang diinginkannya.

c. Bahwa Lingkungan Kerja dan Reward secara bersama-sama dapat mempengaruhi Kinerja Karyawan PT Daya Cipta Dianrancana, yang apabila hal ini dapat dimanfaatkan oleh perusahaan maka akan dapat meningkatkan produktivitas perusahaan.

\section{DAFTAR ISI}

[1] Budianto, A.Aji Tri dan Amelia Kartini. (2015). Pengaruh Lingkungan Kerja Terhadap Kinerja Pegawai Pada PT. Perusahaan Gas Negara (Persero) Tbk SBU Distribusi Wilayah I Jakarta. KREATIF. Jurnal Ilmiah Prodi Manajemen Universitas Pamulang Vol 3, No I Oktober 2015.

[2] Ivancevivh, J.M., R. Konopaske \& M.T. Matteson. (2006). Perilaku dan Manajemen Organisasi Jilid 1. Edisi Ketujuh. Jakarta: Erlangga.

[3] Ivancevich M, John, Robert Konopaske and M. T. Matteson. (2011). Organizational Behavior and Management, Ninth stern, Cengage Learning.

[4] Jason Colquitt, Jeffry A. LePine. (2009). Organizational Behavior, Improving Performance and Commitment in Workplace, New York: McGrow-Hill.

[5] Ivancevich M, John, Robert Konopaske and M. T. Matteson. (2011). Organizational Behavior and Management, Ninth stern, Cengage Learning.

[6] Schermerhorn, John R. (2010), Introduction to Management, Tenth Edition, Canada: John Wiley.

[7] Sutrisno, Edy. 2009. Manajemen Sumber Daya Manusia. Jakarta: Kencana.

[8] Wasiati, Hera. (2018). Pengaruh Reward, Punishment Terhadap Kinerja Pegawai Dengan Kepuasan Kerja Sebagai Variabel Intervening. UPAJIWA. Vol 2 No 1 April 2018. 